\title{
精揉葉乾燥へのマイクロ波加熱の利用※
}

農林水産省野菜・茶業試験場

袴田勝 弘 $^{\dagger}$, 中田典男 ${ }^{1)}$ 向井俊博 ${ }^{\dagger}$,

山口良2), 橋山達二3)

新日本無線株式会社

伊 東 正 晃

(平成 2 年 9 月 3 日受理)

\section{Utilization of Microwave Heating to Drying Process in Crude Tea Manufacturing.}

\author{
Katsuhiro Hakamata - Norio NAKada - Toshihiro, Mukai • \\ Tastuji HASHIYAMA, and Ryou, YAMAGUCHI \\ National Research Institute of Vegetables Ornamental Plants and Tea
}

Masaki ITO

New Japan Radio Co., Ltd.

\section{1 緒言}

新しいメネルギーの伝達方式として注目されてい るマイクロ波は, 食品工業界に扎いて加熱源として の有用性が認められ, 食品の加工・殺菌・保存など 多くの用途に利用されて扣り，小型の装置は, 電子 レンジとして広く普及している。

マイクロ波加熱は, 内部加熱方式といら加熱法の 特徵の他, 操作が簡単で熟練を要しない, 昇降温に 要する時間が短く, 加熱温度の制御が容易等自動化 が可能な要素を備えており, 茶業界において子高周 波発生装置を使用した茶葉の乾燥試験中緑茶の蒸熱 工程・乾燥工程への電子レンジの適用試験が行われ るなど古くから注目されてきた。しかし，装置の能 率性・価格面・バッ千処理等の問題があり, 当時, 実用化は時期尚早とされていた。近年, 小型電子レ ンジの普及に伴い，電子レンジを利用した緑茶製造 法の研究, 釜炒り製玉粶茶製造法の研究や, ベルト コンベア式マイクロ波加熱装置を利用した火入れ法 の検討, 荒茶の仕上げ前乾燥法, 半発酵茶の萎调・殺
青工程への適令等の研究が進められるなどマイクロ 波加熱方式に対する関心が高まりつつある。また， 実用化商品としてベルトコンベア式マイクロ波加熱 装置が開発されるなど，之の利用は広まりつつある が，低然として設備費が高いのが難点である。

このため, マイクロ波加熱の特改を生かし, 䣼素 失活のための蒸熱工程や熱効率が低く能率も良くな い精揉葉乾燥工程等へのマイク口波加熱装置の多用 途利用を図る必要がある。

そこで、本報では，マイクロ波加熱装置の多用途 利用の一環として、ペルトコンベア式アプリケータ を有するマイクロ波加熱装置を供試し，精揉葉乾燥 工程への適用の可能性について検討を加え, 二, 三 の知見を得たので報告する。

\section{2 実 験 方 法}

\section{1 マイクロ波加熱装置の概要}

実験に使用したマイクロ波加熱装固は，茶の火入 れ乾燥機として市販されているベルトコンベア式ア プリケーターを有する装置（新日本無線製 NJE-

\footnotetext{
※製茶工程炕打るマイクロ波加熱の利用（第 1 報）

本報の概要は日本茶業技術研究発表会（1988年11月）に批いて発表した。

$\dagger$ 野菜・茶業試験場 ( 428 静岡県溙原郡金谷町金谷2769)

1）現株式会社寺田製作所， 2）農林水産省野菜・茶業試験場第28期農業技術研修经了生，3）同第29期農 業技術研修修了生

†† 埼玉県茶業試験場（1987）：昭和61年度試験成績（加工流通部）P.56 58
} 


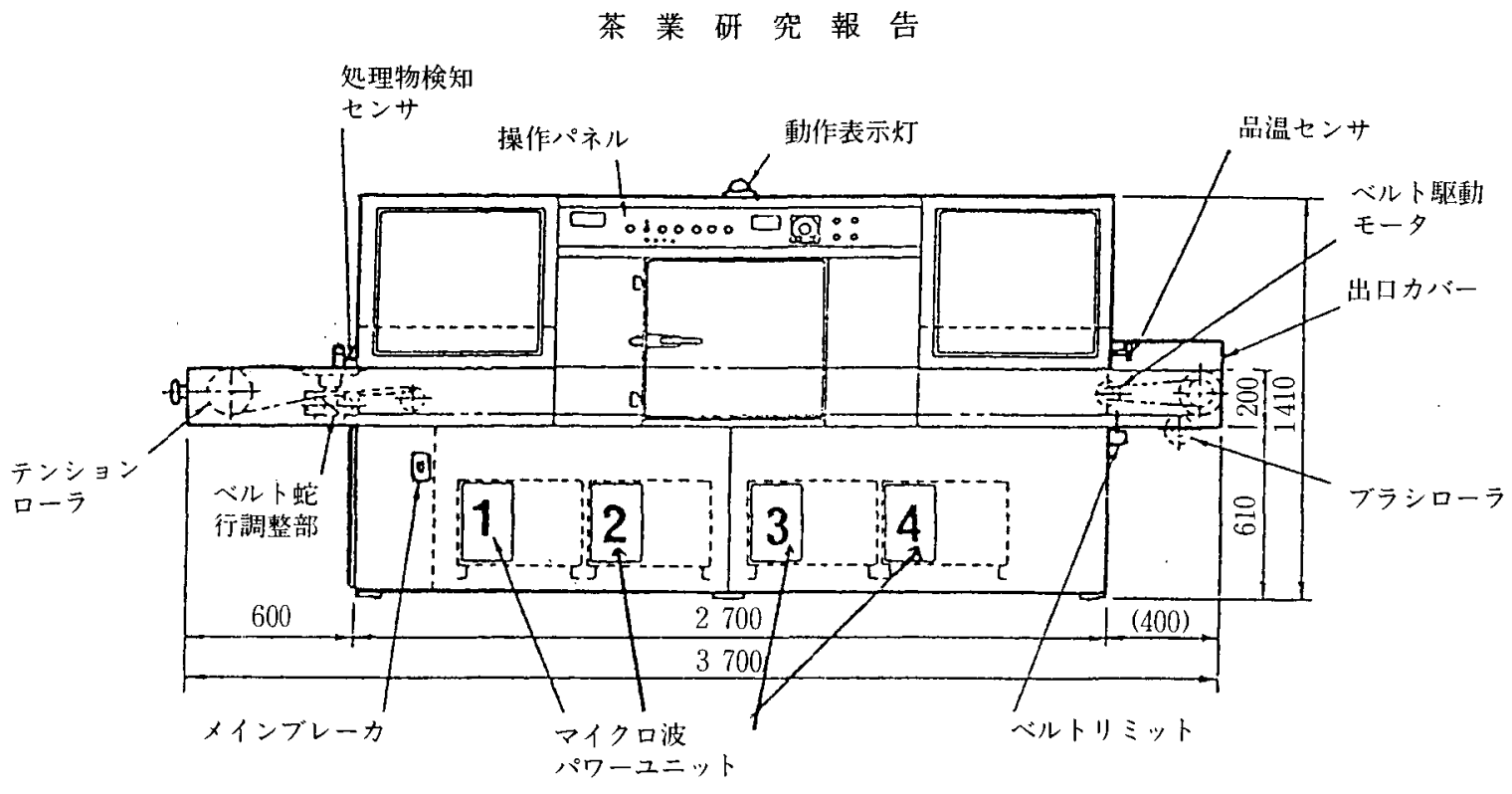

図 1 ベルトコンペア式マイクロ波加熱装置

6010 型) で，その外形図を图 1 に示した。

本装置は，幅 $50 \mathrm{~cm}$ のテフロンコートガラス繊 維製のベルトコンベア（ベルト速度 $0.3 \sim 1.8$ $\mathrm{m} / \mathrm{min}$. 可変) による連続処理が可能なオーブンタ イプである。マイクロ波発振器（発振周波数，2450 $\pm 30 \mathrm{MHz})$ としてマグネトロンを使用し，1.2 kW の可変出力型マイク口波発生機 4 台からそれぞれ導 波管でオーブン内に給電されている。オーブン入口 の処理物検知センサでベルトコンベア上の茶葉が検 知され，検知後，所定時間後（コンベア速度により 決る）に最初に位置する発生機が始動, 葉の移動に 応じて 4 台目まで順次出力が供給されていくシステ ムになって扣り，連続運転中は，4台のユニットが すべて稼動した状態になっている。尚, 開口部出入 口に幅 $65 \mathrm{~cm}$ の電波漏洩防止部が設けられている。

\section{2 供試材料}

可搬式摘採機で摘採した当場 ‘やぶきた’ 成木園 の一，二番茶及び “さやまか扣り’成木園の一番茶 新芽各 $50 \mathrm{~kg}$ を $60 \mathrm{~kg}$ 製茶機で標準製造した精揉葉 を供試した。

\section{3ママイクロ波加熱法による精揉葉の漧蜗}

精揉葉各 $2 \mathrm{~kg}$ をマイクロ波出力 $4.8 \mathrm{~kW}$ ，ベルト 速度 $0.45 \sim 1.76 \mathrm{~m} / \mathrm{min}$. (照射時間 $180 \sim 35$ 秒) の 組合せ条件下でアプリケータ内を通すことにより乾 嬠を行った。

マイクロ波加熱による乾燥は，マイクロ波出力・ 照射時間・被加熱物の単位時間あたり供給量に大き く左右される。本試験では, 予備試験で得た情報か
ら, 熟練者の目視による厚みと, 精揉葉投入に要す る時間を目安に手動供給で行った。乾燥荒茶は, 品 質評価や化学成分分析を行い，マイクロ波加熱によ る乾燥が茶の品質に及注与影響を従来法の熱風乾燥 荒茶と比較検討した。

\section{2 . 4 温度测定}

茶葉葉温測定は $65^{\circ} \mathrm{C}, 70^{\circ} \mathrm{C}, 75^{\circ} \mathrm{C}, 80^{\circ} \mathrm{C}$ で变色 するサーモラベル及び $90^{\circ} \mathrm{C}, 95^{\circ} \mathrm{C}, 100^{\circ} \mathrm{C}, 105^{\circ} \mathrm{C}$ で変色する日油技研工業製のサーモラベルを茶葉表 面に貼付してベルトコンベア上を流すことにより行 った (茶葉表面最高温度)。また, 赤外線放射温度 計（低温用放射温度計パイロスコープL）の焦点を マイクロ波オーブン内ベルトコンベア中央部表面に セットし, 移動するベルト上の葉温の测定(ベルト 上温度とする）を行った。

\section{5 官能検査}

試料の審查は，普通審査法に基いて外観（色沢）, 香気, 水色, 滋味の 4 項目についてそれぞれ 20 点 满点として行った。

\section{6 化学成分の分析}

各荒茶試料は，粉砕後，1 mm 篩を通過したもの を以下の分析に供した。

(1)カフェイン：高速液体クロマトグラフを用いた池 ケ谷の方法で行った。

(2)タンニン：酒石酸鉄を用いる公定分析法に上り定 量した。

(3)遊離アミノ酸組成：高速液体クロマトグラフ法を 用いた高柳等の方法で行った。 
表 1 マイクロ波加熱による精捼葉乾燥時の影響

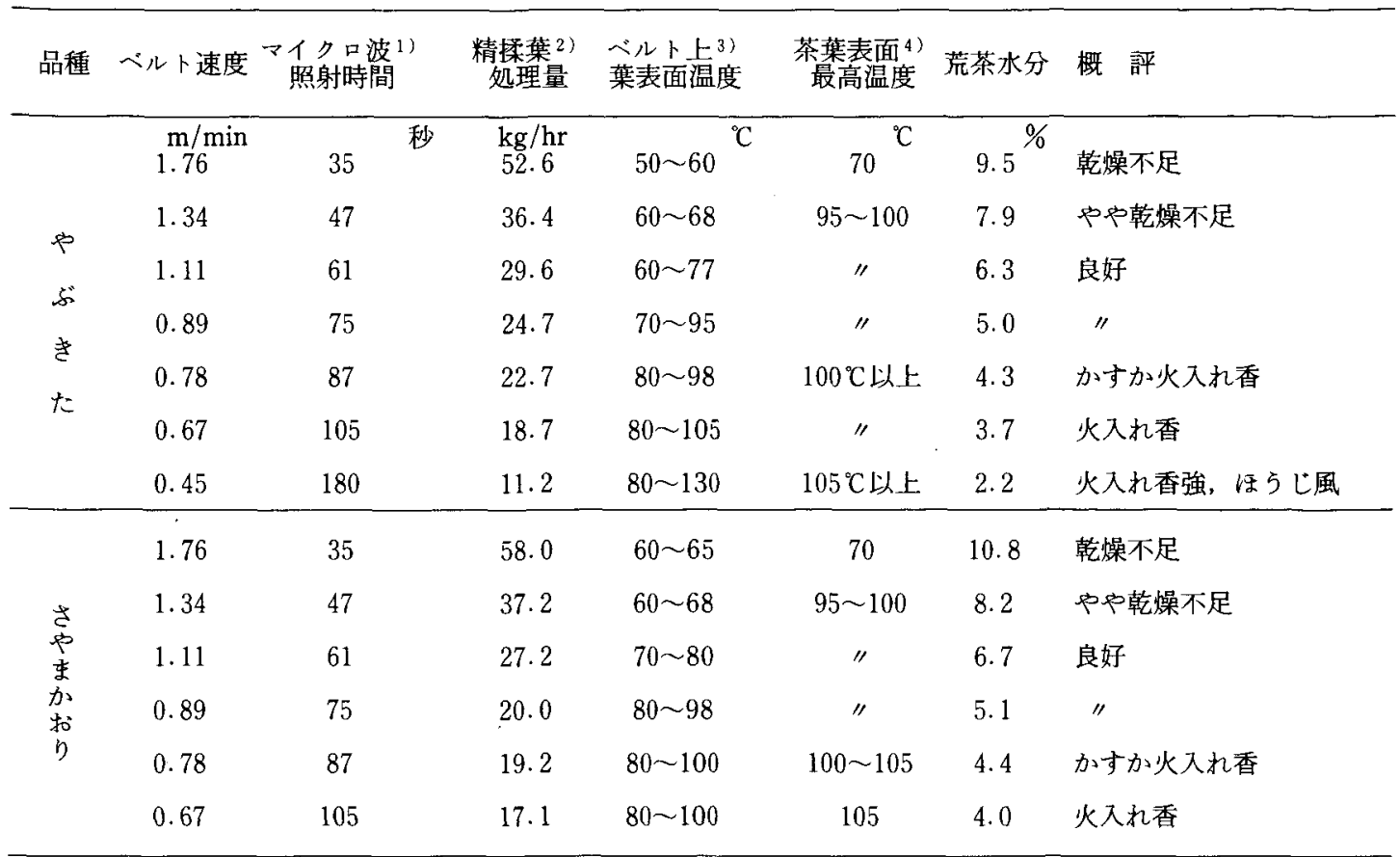

［注］1）マイクロ波出力 $4.8 \mathrm{~kW}$. 22) 1 時間連続処理した場合の推定值． 3) 放射温度計 4) サーモラベル。品種はいずれる1988年一番茶.

(4)アスコルビン酸：高速液体クロマトグラフ法を用 いた池ケ谷等の方法で行った。

\section{7 香気成分の分析}

荒茶からのエーテル抽出物の調製は，茶葉に内標 準物質としてェチルデカノェートを加え，連続蒸 留法で抽出した。香気成分分析は，FID 検出器を 設置したヒューレットパッカードHP-5890A型ガ スクロマトグラフを使用し，J\&W社の内径 0.32 $\mathrm{mm}$ の $60 \mathrm{mDB}-\mathrm{Wax}$ カラムで, $40 \sim 220^{\circ} \mathrm{C}, 4$ ${ }^{\circ} \mathrm{C} / \mathrm{min}$. の昇温条件で行い, 線速度 $20 \mathrm{~cm} / \mathrm{min} て ゙$ $\mathrm{He}$ をキャリアガスに用い, 注入口温度 $180^{\circ} \mathrm{C}$, 検 出器温度 $230^{\circ} \mathrm{C}$, サンプル注入方法にスプリットレ ス法を用いた。分析結果は，島津クロマトパック C $\mathrm{R}-4 \mathrm{~A} に よ り$ リテンションタイム及びピーク面 積を求め，コバッインデックスと内標準エチルデカ ノエートに対する面積比を計算した。

\section{3 実 験 結 果}

\section{1 精揉葉乾燥時の状況}

マイクロ波出力を $4.8 \mathrm{~kW}$ に固定し，照射時間を 変えた条件で精揉葉乾燥を行った時の状況を表 1 に
示した。

マイクロ波加熱による昇温はパワーニニットオン 後極めて短時間に行われ，かつ温度制御が容易であ ることが確認された。

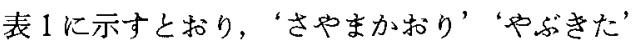
とも同粎の傾向でマイクロ波出力が一定の場合， た ルト速度が速い（照射時間が短い）場合は，精拯葉 処理量は多くなるがベルト上温度, 茶葉表面最高温 度とむ上らず乾燥不足で, 含水率の多い荒茶となり, 品質低下の原因となった。逆にベルト速度が遅い（照 射時間が長い) 場合㲦燥過度となり，0.45 $\mathrm{m} / \mathrm{min}$. (照射時間 180 秒) ではごルト上温度も 120 ${ }^{\circ} \mathrm{C}$ 以上となり，㭱らじ風の香りを生じた。また，0.67 $\sim 0.78 \mathrm{~m} / \mathrm{min} .(105 \sim 87$ 秒) では，火入れ香が感じ られた。一方，ベルト速度 $0.89 \sim 1.10 \mathrm{~m} / \mathrm{min}$. (75 〜60秒) での乾燥状態（触感）は良好であった。 この時の精揉葉処理量は $20 \sim 30 \mathrm{~kg} / \mathrm{hr}$. と推定され た。尚，二番茶の精揉葉漧燥試験でも注汇同様の傾 向が認められた。

乾燥直後の荒茶の状況 (触感) から乾燥不足と判 断されるものは $7 \%$ 以上の水分含有率を，また乾燥 
表 2 官能検查結果

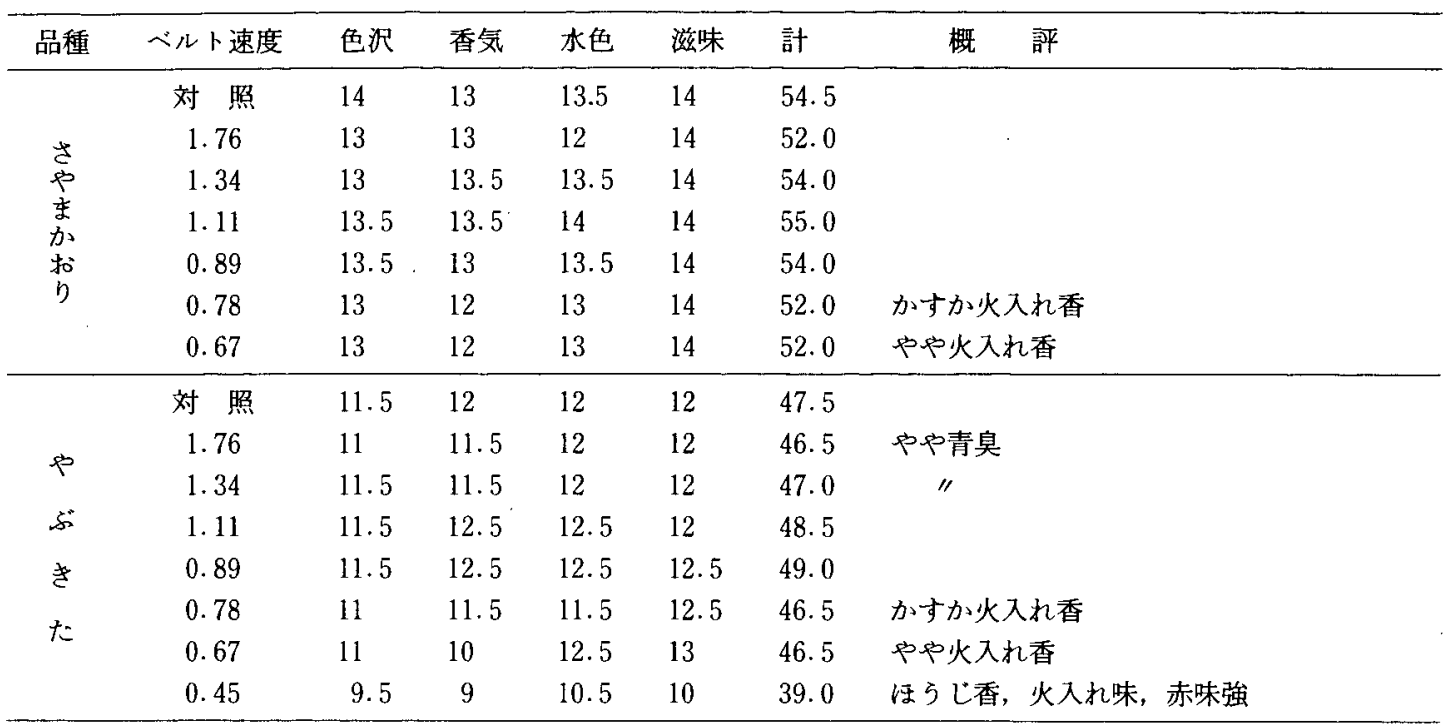

[注］マイクロ波出力 $4.8 \mathrm{~kW}$, ベルト速度 $\mathrm{m} / \mathrm{min}$

対照は熱風乾燥（従来法）, ‘ぶきた”は一番茶後期（やや深蒸し）

表 3 マイクロ波加熱による精揉葉翰燥が荒茶の化学成分に及洼す影響

\begin{tabular}{|c|c|c|c|c|c|c|c|c|c|}
\hline 品種 & ベルト速度 & Tannin & Caffeine & Ascorbic acid & Thea. & $\underset{\text { Asp.A. }}{A n}$ & $\begin{array}{l}\text { nino Aci } \\
\text { Glu.A. }\end{array}$ & Gln. & Arg. \\
\hline \multirow{6}{*}{$\begin{array}{l}\text { p } \\
\xi \\
\text { } \\
た\end{array}$} & $\mathrm{~m} / \mathrm{min}$ & $\%$ & $\%$ & $\mathrm{mg} \%$ & $\mathrm{mg} \%$ & $\mathrm{mg} \%$ & $\mathrm{mg} \%$ & $\mathrm{mg} \%$ & $\mathrm{mg} \%$ \\
\hline & 1.76 & 12.7 & 2.36 & 390 & 1038 & 187 & 244 & 240 & 97 \\
\hline & 1.34 & 12.7 & 2.32 & 461 & - & - & - & - & - \\
\hline & 0.89 & 12.7 & 2. 30 & 539 & 1001 & 170 & 229 & 218 & 90 \\
\hline & 0.67 & 12.4 & 2.26 & - & - & - & - & - & \\
\hline & 0.45 & 12.7 & 2.38 & 484 & 685 & 141 & 160 & 100 & 70 \\
\hline \multirow{7}{*}{ 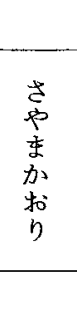 } & 対照 & 12.9 & 2.37 & 480 & 1025 & 183 & 258 & 231 & 105 \\
\hline & 1.76 & 14.5 & 2.57 & 431 & & & & & \\
\hline & 1.34 & 14.3 & 2.53 & 488 & & & & & \\
\hline & 0.89 & 13.9 & 2.58 & 545 & & & & & \\
\hline & 0.78 & 14.0 & 2.49 & - & & & & & \\
\hline & 0.67 & 14.2 & 2.62 & 590 & & & & & \\
\hline & 対照 & 14.0 & 2.55 & 551 & & & & & \\
\hline
\end{tabular}

［注］いずれる1988 年一番茶を使用した.アミノ酸は 1989 年一番茶. 対照は表 2 脚注参照

しすぎと判断されたものは $4.5 \%$ 以下の水分含有率 を示し，良好と判断された $0.89 \sim 1.10 \mathrm{~m} / \mathrm{min}$. の 畭燥条件では $5 \sim 6.5 \%$ の水分含有率を示した。

\section{2 荒茶品質}

マイクロ波加熱により乾燥した精揉葉を普通審査 法で評価した結果を表 2 に示した。

普通審查法による品質評価の結果は，乾燥直後の 茶葉を触感でチェックした結果（表 1 ）と泳ぼ同様 の傾向となり，ベルト速度 $0.78 \mathrm{~m} / \mathrm{min}$ 上り遅い区
では火香や火入れ味が認められた。とくに0.45 $\mathrm{m} / \mathrm{min}$ 区では葉色も褐色味を帯び，济うじ風の香 味となり，水色も赤味を帯びたため品質評点が著し く低くなった。また，乾燥不足の評価を受けたベル 卜速度の速い区では青臭が感じられ, 品質評価をや や下げる原因となった。ベルト速度 $0.89 〜 1.10$ $\mathrm{m} / \mathrm{min}$. では，外観・内質とも対照区（熱風乾燥） と同等か上回る值を示した。

尚，“さや年扣り’と・やぶきた’の品種間に 
大きな品質の開きがあるが，これは品種間差ではな く，摘採商期に摘まれた ‘さやまか和り’と摘採期 後期に摘まれた ‘やぶきた”の製茶原料の違いによ るものである。

\section{3 化学成分，香気成分の分析}

化学成分, 香気成分の分析結果をそれぞれ表 3 , 表 4 に示した。

化学成分は, アスコルピン酸含量がベルト速度の速 い区で，アミ，酸含量が逆にベルト速度の遅い（0. $45 \mathrm{~m} / \mathrm{min}$.)区で著しく少なかった他は，カフェイン， タンニン含量とも対照区とほとんど差は認められな かった。

香気成分炕ついては，品質の良かったベルト速度 $0.89 \mathrm{~m} / \mathrm{min}$ 区と対照区について調べたが，マイク 口波乾燥区でネロリドールが著しく多く，逆に対照 区でリナロール，ゲラニオールがやや多くなってい

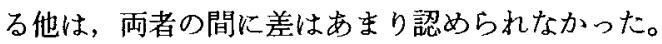

\section{4 考察}

精揉葉乾燥工程は，水分 $13 \%$ 前後の精揉葉を 5 \%前後まで熱風により乾燥するのが目的であるが， 他の緑茶製造工程に比べ熱効率が低い上，能率も良 〈ない。

一方，マイクロ波加熱による乾燥は，内部加熱方 式のため，外部に逃げる余分な熱が汪とんどないの で一般に効率の良い加熱が可能で，短時間で乾燥で きるといら利点を持って拉り，特に低水分領域での 乾燥に適していると考えられている。

これを利用した装置は茶に打いても仕上げ工程の 乾燥機として実用化されて和り，その有利性が報告 されているが，精揉葉乾燥工程に利用した報告はな い。

本試験では，この装置の多用途利用の一環として 精揉葉乾燥工程への適用の可能性について検討し， 乾燥時の茶葉の状態, 官能検查, 化学成分分析の結 果から，加熱条件さ光選べば従来法の熱風乾燥の製 品と㖨色ない荒茶が得られることを確認した。この 最も良い品質の荒茶を得られるマイク口波加熱条件 は, 出力 $4.8 \mathrm{~kW}$ ではべルト速度 $0.89 \sim 1.11$ $\mathrm{m} / \mathrm{min}$ の範囲にあり，またマイク口波照射時間は わずか $60 \sim 75$ 秒で，従来の透気乾燥に比べ大幅な 乾燥時間の短縮となった。この条件で乾燥した荒茶

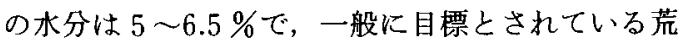
茶の水分含有率 $5 \%$ 前後に注湆合う数值を示し た。また，表 1 ，表 2 に示されるように乾燥直後の
表 4 マイクロ波加熱による精菜葉乾燥が 茶の主な香気成分に及ぼす影響

\begin{tabular}{lcc}
\hline \multicolumn{1}{c}{ 分 } & 対照(熱風) & マイク口波 \\
\hline Heptanal & 0.44 & 0.38 \\
1-Pentanol & 0.05 & 0.02 \\
(z)-2-Penten-1-ol & 0.02 & 0.02 \\
(z)-3-Hexenol & 0.04 & 0.03 \\
Linalool & 0.60 & 0.36 \\
1-Octanol & 0.17 & 0.15 \\
(z)-3-Hexenyl hexanoate & 0.13 & 0.15 \\
Geraniol & 0.23 & 0.15 \\
(z)-Jasmone & 0.06 & 0.04 \\
Nerolidol & 1.87 & 2.82 \\
Indole & 0.19 & 0.13 \\
\hline
\end{tabular}

[注］マイク口波加熱条件は $4.8 \mathrm{~kW}, 0.89 \mathrm{~m} / \mathrm{min}$. 香気成分は内標集物質（エチルデカノェート） のピーク面積に対する比 品種は 1988 年一番茶“やぶきた’。

茶葉の状態が乾燥不足と判断されたものや，火入れ 香が感じられるようなものは，いずれる官能検查に よる品質の評価が低くなって扣り，乾燥直後の茶葉 の状態から乾燥の良否をある程度判断できると考兄 られた。

尚，本試験での品質評価は，荒茶といら観点で行 ったため，火入れ香が感じられるるのは減点の対象 となり，いずれも品質評点は低くなったが仕上げ茶 の観点からは適度の香味と考克られ，乾燥不足区の 品質よりまさる傾向であった。

阿南らは荒茶中の化学成分の加熱による变化を調 ベ，カフェイン含量は加熱の影響を受けないが，ア ミ，酸類，ビタミンC，タンニン等の含量が減少し， 特にアミノ酸類, ビタミンCの減少が著しいことを 報告している。本試験に打いて表 3 に示すよらにべ ルト速度の遅い $0.45 \mathrm{~m} / \mathrm{min}$. (加熱強度大) 処理区 の葉中カフェイン，アミ／酸類で同様の傾向を認め た。しかし，ビタミンC，タンニンの結果は必ずし も一致していない。この原因についてはよくわから ないが，阿南らの報告は荒茶を供試し，加熱も熱風 循環式定温乾燥器を用いた結果であるのに対し，本 試験では，水分含量の多い精揉葉を供試し，内部加 熱方式であるマイク口波加熱法によるなど，加熱方 法も異なっていることも何らかの影響を与えている と思われるので，今後更に検討する必要があると考 えられる。 
一方，好適な条件下でのマイク口波乾燥荒茶の力 フェイン，タンニン等の呈味成分や香気成分はとる に対照区（熱風乾燥）と大差なく，マイク口波加熱 による乾燥が悪影響を及ぼすことはないと判断され た。

以上述べたようにマイクロ波加熱による乾燥は, 条件さえ選べば十分精揉葉乾燥に適用できることが 認められた。さらに本装置は, ベルトコンベア式で 茶葉の連続処理ができ，昇降温に要する時間が短く かつ温度制御が容易であることから自動化が可能で あり，荒茶製造工程に十分組み入れることが可能と 考えられた。

本試験に使用した装置では，良好な乾燥条件にお ける精揉葉処理量は $20 \sim 30 \mathrm{~kg} / \mathrm{hr}$ と推定されるが， マイクロ波出力が大きい容量のものでは, 当然処理 量も増加できると考えられる。しかし，単位時間む たりの処理量を増やすために, 茶葉の厚みを增しす ぎると乾燥不足をまねくので注意が必要である。 た，マイク口波加熱の性質上，茶葉層表面より内部 の方が温度が高くなるので, 茶葉層を厚くした時下 部の莱温が上がりすぎない様留意する必要がある。

\section{5 摘要}

ベルトュンベア式マイクロ波加熱装置の多用途利 用を図るため, 荒茶製造工程のらち, 精揉葉乾燥工 程への適用について検討した。

1.マイク口波加熱による乾燥は 60〜75秒ですみ 従来法 (熱風乾燥) に比へ乾燥時間を大幅に短縮す ることができた。また，界降温に要する時間が短く 温度制御が容易であった。

2. 啇度のマイクロ波加熱では, 熱風乾燥法と同等 か上回る品質の荒茶が得られたが，マイク口波照射 時間が短かすぎると乾燥不足となり，逆に長すぎる と火入れ香やほ た。

3.マイク口波出力 $4.8 \mathrm{~kW}$, 照射時間 $60 \sim 75$ 秒

（精揉葉処理量 20〜30 kg/hr）の範囲で従来法の代 替が可能と考点られた。

4.この時の荒茶水分 $5 \sim 6.5 \%$ で, 主要子ミノ酸, カフェイン, タンニン, アスコルビン酸含量や主要 香気成分含量も熱風乾爆荒茶とほぼ同等の值を示し た。

\section{6 引用文 献}

1）露木英男（1982）：食品工業に和ける高周波打 よびマイクロ波加熱の利用，日食工誌 29 , $123 \sim 130$.

2）紅林 勇・松浦敏夫（1951）：高周波並に赤外 線による茶葉の乾燥試験，茶技研 No. 4, 16 $\sim 25$.

3) 桑原穆夫 (1969)：マイクロ波加熱と茶, 茶 22 (10) $84 \sim 87$.

4）深津修一・岩浅 潔（1987）：電磁波を利用し た茶の製造，茶技研 No.65（講要）135～ 136.

5 ）広瀬真一・松尾志保・稲垣智之（1989）：かま いり製玉緑茶製造工程に㧍ける電磁波の利用, 茶研報 No. 70 (別冊) 88 90.

6 ）柴田長吉郎 (1986) : 茶葉の乾燥装置, 柴田長 吉郎編, 工業用マイクロ波応用技術, 電気書院, P. $137 \sim 140$.

7 ）落合勝義（1989）：電磁波を利用した夏茶の香 味改善, 関東東海農業の新技術 No. 5 282 286 .

8 ）松本五十生 - 森田貞夫 ・落合勝義 -中村公一 （1989）：新香味茶製造技術の開発（第 1 報） 萎调及び発酵技術, 茶研報 No. 70（別冊） 93 94.

9）吉冨 均・中野不二雄・滝谷 洋 - 鈴木勝弘 鈴木三郎・岩浅 潔・斉藤 弘・深津修一・田 中伸三・岩珮源五郎・萩原 豊（1983）：製茶 機械の熱効率 茶研報 No. 58 (講要)，52 54.

10）池ヶ谷賢次郎（1985）：高速液体クロマトグラ フィーによる苯のカフェインの定量法, 日食工 誌, 32, 61 66 .

11）化学研究室 (1970) : 茶の公定分析法, 茶試研 報, No. $6,167 \sim 172$.

12）高柳博次・阿南豊正・池ヶ谷賢次郎（1989）： 高速液体クロマトグラフィーによる茶のアミ， 酸類の定量 茶研報, No. $69 \quad 29 \sim 34$.

13）池ヶ谷賢次郎・高柳博次・阿南豊正・(1990)： 茶の分析法, 茶研報, No. $71 \quad 43 \sim 74$.

14）堀田 博 - 原利男（1984）：連続水蒸気蒸留 エーテル抽出法による茶香気成分の分析, 茶技 研, No. $66,41 \sim 46$. 


$$
\text { 第 } 72 \text { 号 } \quad\left(\begin{array}{llll}
1 & 9 & 9 & 0
\end{array}\right)
$$

15) Jennings W. (1978) : Gas Chromatography with Glass Capillary Columns, Academic press; New York, San Fransisco and London, P. 76.

16）枈田長吉郎（1988）：マイクロ波乾燥法, 食品加 工技術 8 (4) 294 302.

17）阿南豊正・天野いね・中爪致之（1981）：緑茶の 化学成分の加熱に上る变化, 日食工誌 28,74 78 .

\section{Summary}

Application of microwave heating to the drying process of green tea manufacture was studied by using a microwave heating apparatus of a belt conveyor type (NJE-6010). The apparatus has microwave power units of maximum $4.8 \mathrm{~kW}(1.2 \mathrm{~kW} \times 4)$ at $2450 \mathrm{MHz}$ and a teflon-coated glassfiber belt of $50 \mathrm{~cm}$ wide, which moves at a speed between 0.3 and $1.8 \mathrm{~m} / \mathrm{min}$. Microwave heating is benefitable for rising the tea leaf temperature rapidly, which can be maintained constant by use of simple controller. Thus a considerable reduction in time of drying finally rolled leaves was achieved as compared with the conventional method of hot air drying.

Quality of green tea dried by microwave method under the appropriate condition was almost the same or superior to that of conventionally dried tea.

When finally rolled leaves( $13.5 \%$ moisture) was irradiated with microwave in the apparatus for 60 $\sim 75 \mathrm{sec}$, the tea contained moisture of $5 \sim 6.5 \%$, and as much amino acids, caffeine, tannin, ascorbic acid, and aroma compounds as conventionally dried tea.

It is concluded that microwave heating can be employed as an alternative method to the conventional method in green tea manufacture.

(Sep. 3, 1990) 